Available online at

INSECTA

Integrative Science Education and Teaching Activity Journal

Journal homepage : https://jurnal.iainponorogo.ac.id/index.php/insecta

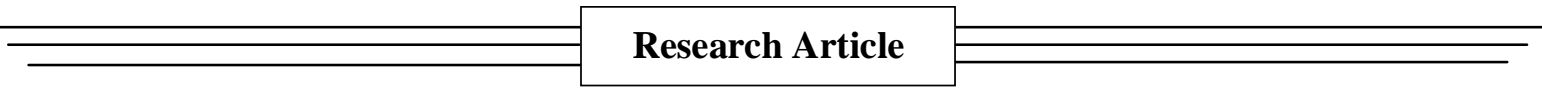

\title{
Students' Response to the Implementation of Case Based Learning (CBL) Based on HOTS in Junior High School
}

\author{
Handika Arianto*, Hanin Niswatul Fauziah \\ Jurusan Tadris Ilmu Pengetahuan Alam, Fakultas Tarbiyah dan Ilmu Keguruan, \\ Institut Agama Islam Negeri (IAIN) Ponorogo
}

*Corresponding Address: Handikaarianto16@gmail.com

\section{Article Information}

Article history:

Received: June 23, 2020

Accepted: June 27, 2020

Published: June 27, 2020

KeyWords:

Case Based Learning,

HOTS,

Students' Response

\section{Kata Kunci:}

Case Based Learning, HOTS,

Respon Peserta Didik

\begin{abstract}
The aim of this research is to determine students' response to the implementation of Case Based Learning (CBL) based HOTS in one of Junior High School of Ponorogo District. Data collected by questionnaire and interview. Then tabulated in Microsoft Excel and analyzed descriptively. Results of the study showed that the average of students' response is 3.2. These results indicate that the students' response were very good. Case Based Learning (CBL) based HOTS made students more fun, motived, skilled, and active in learning.
\end{abstract}

\begin{abstract}
ABSTRAK
Penelitian ini bertujuan untuk mengetahui respon peserta didik terhadap model pembelajaran Case Based Learning (CBL) berbasis HOTS di salah satu SMP di Kabupaten Ponorogo. Instrumen dalam penelitian adalah kuisioner dan wawancara. Data yang telah diperoleh ditabulasi dalam Microsoft Excel kemudian dianalisis secara deskriptif. Hasil penelitian menunjukkan bahwa, nilai rata-rata kuisioner peserta didik sebesar 3,2. Nilai tersebut menunjukkan bahwa respon peserta didik terhadap model pembelajaran Case Based Learning (CBL) berbasis HOTS sangat baik. Model pembelajaran Case Based Learning (CBL) berbasis HOTS membuat peserta didik senang, termotivasi, dan semakin aktif dalam pembelajaran.
\end{abstract}

Published by Tadris Ilmu Pengetahuan Alam Department, IAIN Ponorogo, Indonesia.

\section{PENDAHULUAN}

Pembelajaran berbasis masalah merupakan pembelajaran yang menyajikan masalah dunia nyata untuk diselesaikan oleh peserta didik. Menurut (Sani, 2014) Problem Based Learning (PBL) merupakan pembelajaran yang penyampaiannya dilakukan dengan cara menyajikan suatu permasalahan, mengajukan pertanyaan-pertanyaan, memfasilitasi 
penyelidikan, dan membuka dialog. Permasalahan yang dikaji hendaknya merupakan permasalahan kontekstual yang ditemukan peserta didik dalam kehidupan sehati-hari.

Model pembelajaran berbasis masalah menekankan pada proses penyelidikan dalam menyelesaikan masalah dunia nyata, sehingga dapat membuat respon peserta didik terhadap proses pembelajaran menjadi aktif serta dapat meningkatkan kemampuan berpikir kritis peserta didik dalam menyelesaikan masalah. Model Problem Based Learning merupakan suatu model pembelajaran yang menggunakan masalah dunia nyata bagi suatu konteks bagi peserta didik untuk belajar tentang berfikir kritis dan keterampilan memecahkan masalah serta untuk memperoleh pengetahuan dan konsep yang esensi dari materi pelajaran (Rusman, 2011).

Pada saat ini peserta didik cenderung kurang aktif, dan kurang termotivasi dalam kegiatan pembelajaran yang dilakukan. Hal tersebut terjadi karena kurang beragamnya model pembelajaran yang guru terapkan pada saat proses pembelajaran serta kurangnya keberanian peserta didik dalam bertanya pada teman atau guru karena berbagai alasan. Permasalahan dalam pembelajaran tersebut salah satunya terjadi di SMP Negeri 1 Mlarak. Berdasarkan pengamatan pada saat proses pembelajaran dan hasil wawancara kepada guru di SMP Negeri 1 Mlarak, ditemukan beberapa permasalahan di dalam proses pembelajaran, salah satunya yaitu kurangnya minat dan motivasi belajar IPA pada kelas VIII. Rendahnya minat belajar IPA ini karena pembelajaran berpusat pada gru dan kurang menggunakan metode problem soving sehingga minat belajar peserta didik dalam kategori rendah.

Berdasarkan permasalahan tersebut maka diperlukan metode pembelajaran yang dapat meningkatkan respon dan motivasi peserta didik, salah satu model pembelajaran tersebut adalah Case Based Learning. Case Based Learning atau pembelajaran berbasis kasus, pertama kali dikeluarkan atau dikenalkan kepada dunia pendidikan pada akhir 1800an, dan banyak digunakan di dunia ekonomi pada tahun 2019. Case Based Learning merupakan model pembelajaran berbasis project dan masalah. Dimana peserta didik merupakan subyek yang dituntut untuk memecahkan kasus-kasus klinis yang berkaitan dengan tujuan pembelajaran. Karakteristik utama dari CBL ini diperoleh dari Problem Based Learnng (PBL) yang berbasis kasus atau inkuiri (penyelidikan) terhadap sebuah kejadian konkret dan sesuai konteks yang dihadapi peserta didik (Dewi \& Hamid, 2015).

Indikator dalam pembelajaran CBL adalah, 1) konsep dasar, 2) pendefinisian masalah, 3) pembelajaran mandiri, 4) pertukaran pengetahuan, 5) asessment. Dari beberapa indikator diatas dalam pelaksanaan pembelajaran dilapangan haruslah menekankan pada penyelesaian kasus-kasus faktual dan terbaru (Sari \& Nurohmah, 2016). Selain itu peran tenaga pendidik untuk menstimlus peserta didik agar mampu lebih aktif dalam menyelesaika masalah juga sangat diperlukan agar peserta didik lebih termotivasi dan mampu menyelesaikan berbagai masalah yang mereka hadapi.

Untuk semakin menunjang model pembelajaran Case Based Learning, peneliti menggunakan penunjang yaitu High Order Thingking Skils (HOTS). HOTS merupakan kemampuan berpikir tingkat tinggi. Di dalam konsep HOTS mencakup problem solving atau pemecahan masalah dan pengambilan keputusan (Dinni, 2018). Hal itu juga sejalan dengan model pembelajaran Case Based Learning (CBL) yang juga berbasis pada studi kasus atau masalah.

Kurang beragamnya model pembelajaran yang dilakukan oleh tenaga pendidik membuat respon pesera didik terhadap proses kegiatan pembelajaran yang kurang baik. Dengan mengunakan model pembelajaran Case Based Learning (CBL) berbasis HOTS diharapkan mampu membuat respon pembelajaran peserta didik menjadi lebih baik. Salah satu indikator respon peserta didik yang baik yaitu menunjukkan kemampuan pemecahan masalah secara matematis (Chotimah, 2014). Tujuan penelitian ini untuk mengetahui respon 
peserta didik terhadap model pembelajaran Case Based Learning(CBL) berbasis HOTS di SMP Negeri 1 Mlarak.

\section{METODE}

Penelitian ini dilaksanakan pada bulan Februari hinggaMei 2020. Pengambilan data dilaksanakan diSMP Negeri 1 Mlarak Ponorogo yang terletak di Jl. Raya Mlarak No. 2. Pengambilan data dilakukan dengan cara membagikan kuisioner dan wawancara terhadap 30 peserta didik kelas VIII. Lembar kuisioner disusun dengan menggunakan skala Likert berjenjang 4. Data yang telah diperoleh kemudian ditabulasi dalam Microsoft Excel dan dianalisis secara deskriptif. Analisis kuisioner menggunakan kategorisasi respon yang disajikan pada tabel berikut.

Tabel 1.Indeks Kategori Angket/Kuisioner Respon Peserta Didik

\begin{tabular}{cc}
\hline Skor & Interpretasi \\
\hline $3 \leq$ skor $\leq 4$ & Sangat baik \\
$2 \leq$ skor $<3$ & Baik \\
$1 \leq$ skor $<2$ & Cukup \\
$0 \leq$ skor $<1$ & Kurang baik \\
\hline \multicolumn{2}{r}{$($ Ali, 2009) }
\end{tabular}

\section{HASIL DAN PEMBAHASAN}

Berdasarkan hasil penelitian diketahui bahwa respon peserta didik terhadap model pembelajaran Case Based Learning (CBL) berbasis HOTS tergolong sangat baik. Hal ini berdasarkan hasil analisis kuisioner yang menunjukkan nilai rata-rata sebesar 3,2 (Tabel 2). Model pembelajaran Case Based Learning (CBL) berbasis HOTS mendapat respon sangat baik karena dengan diterapkanya model pembelajaran Case Based Learning (CBL) berbasis HOTS, peserta didik lebih senang untuk belajar, lebih mudah untuk melakukan pengamatan, lebih mudah untuk menemukan fakta, menggunakan pengalaman, mengaplikasikan pengetahuan dalam kehidupan sehari-hari, mengaplikasikan hubungan antara materi dan fakta sehingga mereka lebih mahir dalam mencari serta menggali ilmu pengetahuan melalui fakta yang telah mereka temukan, dengan demikian kemampuan antar peserta didik lebih baik dalam memahami materi pembelajaran yang dipelajari.

Tabel 2.Nilai Rata-rata ResponPesertaDidikTerhadap model pembelajaran Case Based Learning (CBL) berbasis HOTS

\begin{tabular}{clc}
\hline No. & \multicolumn{1}{c}{ Pertanyaan } & Nilai \\
\hline $\mathbf{1}$ & Ide Baru & 3.2 \\
$\mathbf{2}$ & Motivasi & 3.1 \\
$\mathbf{3}$ & Aktif & 3.2 \\
$\mathbf{4}$ & Pemahaman Materi & 3.1 \\
$\mathbf{5}$ & Rajin & 3.1 \\
$\mathbf{6}$ & Berani Dalam Berdiskusi & 3.2 \\
$\mathbf{7}$ & Penyelesaian Masalah & 3.2 \\
$\mathbf{8}$ & Penyelesaian Masalah Kontekstual & 3.2 \\
$\mathbf{9}$ & Menarik & 3.2 \\
& Rata-rata & 3.2 \\
\hline
\end{tabular}

Hasil kuisioner ini juga didukung oleh hasil wawancara dengan Khoirunnisa yang menyatakan bahwa model Case Based Learning (CBL) berbasis HOTS dapat membuat peserta didik lebih aktif untuk menyelesaikan masalah, tidak bosan, meningkatkan rasa 
keingintahuan karena peserta didik terlibat langsung dalam pemecahan masalah berbasis studi kasus.

Pada saat proses pembelajaran dengan model Case Based Learning (CBL) berbasis HOTS, peserta didik antusias dan lebih termotivasi terhadap materi yang diberikan. Selain itu peserta didik lebih aktif dalam kegiatan belajar mengajar, aktif dalam berdiskusi menemukan pemecahan kasus yang diberikan, dan yang paling penting peserta didik mampu menghubungkan materi yang telah mereka terima dalam kehidupan sehari-hari. Pembelajaran dengan model baru tersebut membuat peserta didik antusias dan senang, dapat dilihat dari peserta didik yang selalu antusias setiap diberikan sebuah permasalahan, karena permasalahan tersebut sesuai dengan apa yang mereka temui di kehidupan sehari-hari. Selain itu juga ditampilkannya video-video pembelajaran yang berkaitan dengan peristiwa getaran dan gelombang sehari-hari membuat kegiatan pembelajaran menjadi lebih menarik dan tidak membosankan. Hal ini sesuai dengan pendapat (Mustofa et al., 2016) yang menyatakan bahwa model pembelajaran Case Based Learning (CBL) membuat pembelajaran menjadi lebih menarik dan tidak membosankan.

Hasil kuisioner menunjukkan bahwa Case Based Learning (CBL) berbasis HOTS membuat peserta didik tidak bosan dan lebih termotivasi untuk mengikuti pelajaran. Model pembelajaran ini membuat peserta didik lebih aktif dalam memecahkan berbagai kasus yang diberikan dalam materi yang dipelajari. Hal ini karena dalam proses pembelajaran peserta didik selalu aktif dan dapat berpikir kritis dalam menyelesaikan masalah atau kasus-kasus yang mereka hadapi dalam kehidupan sehari-hari. Rasa ingin tahu peserta didik juga semakin meningkat karena model pembelajaran yang mereka rasakan berbeda dari sebelumnya. Hal ini sesuai dengan pendapat (Sani, 2014) yang menyatakan bahwa model pembelajaran berbasis kasus atau masalah membuat peserta didik menyelidiki dan menyelesaikan masalah nyata, sehingga peserta didik terlibat aktif dalam pembelajaran serta dapat meningkatkan kemampuan berpikir kritis peserta didik dalam menyelesaikan masalah.

Dengan menggunakan model pembelajaran Case Based Learning (CBL) berbasis HOTS peserta didik lebih aktif dalam menemukan ide-ide baru ketika menemui sebuah permasalahan atau kasus, lebih mudah untuk melakukan pengamatan kejadian sehari-hari, lebih mudah untuk menemukan fakta, menggunakan pengalaman, mengaplikasikan pengetahuan, mengaplikasikan hubungan antara materi dan fakta. Hal ini menjadikan peserta didik lebih mahir dalam mencari informasi melalui fakta-fakta yang telah mereka temukan, dengan demikian kemampuan berpikir kontekstual peserta didik lebih baik lagi. Selain itu, kemampuan berdiskusi peserta didik menjadi lebih baik setelah dilakukannya model pembelajaran Case Based Learning (CBL) berbasis HOTS, sehingga peserta didik lebih aktif dalam berdiskusi menyelesaikan masalah atau kasus yang telah diberikan.

Faktor-faktor yang mempengaruhi respon peserta didik tersebut diantaranya adalah kegiatan pembelajaran lebih menarik dan tidak monoton sehingga motivasi peserta didik meningkat, kerjasama antar peserta didik dalam kelompoknya dan saling membantu menyelesaikan masalah yang dihadapi, selain itu juga peserta didik lebih memahami konsepkonsep pembelajaran IPA melalui model pembelajaran Case Based Learning (CBL) berbasis HOTS tersebut (Mustofa et al., 2016).

Model Case Based Learning (CBL) berbasis HOTS mendapat respon yang sangat baik dari peserta didik dan meningkatkan kemampuan berpikir kontekstual peserta didik. Hal ini karena pada saat proses pembelajaran dengan menggunakan model Case Based Learning (CBL) berbasis HOTS, peserta didik lebih cepat memahami materi yang diberikan. Hal ini sesuai dengan penelitian yang dilakukan oleh (Dewi \& Hamid, 2015) yang mengemukakan bahwa model pembelajaran Case Based Learning (CBL) berpengaruh secara signifikan terhadap pemahaman konsep peserta didik. Hasil penelitian ini juga didukung oleh hasil penelitian yang dilakukan (Setiawan \& Nyoman, 2008) yang menunjukkan bahwa 
pembelajaran berbasis kasus menstimulus pesera didik untuk lebih aktif, membuat rasa ingin tahu peserta didik meningkat, serta meningkatkan kemampuan penguasaan dan pemahaman konsep.

\section{KESIMPULAN}

Berdasarkan uraian diatas, dapat disimpulkan bahwa respon peserta didik terhadap model pembelajaran Case Based Learning (CBL) berbasis HOTS sangat baik. Hal ini berdasarkan hasil rata-rata kuisioner yang menunjukkan nilai rata-rata sebesar 3,2. Model pembelajaran Case Based Learning (CBL) berbasis HOTS mendapat respon yang sangat baik karena model pembelaran ini bersifat inovatif dan menstimulus peserta didik untuk semakin aktif dalam menyelesaikan segala permasalahan serta meningkatkan motivasi peserta didik dalam mengikuti pelajaran yang dilakukan.

\section{REFERENSI}

Ali, M. (2009). Pengembangan media pembelajaran interaktif mata kuliah medan elektromagnetik. Jurnal Edukasi Elektro, 5(1).

Chotimah, N. H. (2014). Pengaruh Model Pembelajaran Generatif (MPG) Terhadap Kemampuan Pemecahan Masalah dan Disposisi Matematis Siswa di Kelas X pada SMA Negeri 8 Palembang. Skripsi. Universitas PGRI Palembang.

Dewi, C. A., \& Hamid, A. (2015). Pengaruh Model Case Based Learning (CBL) Terhadap Keterampilan Generik Sains dan Pemahaman Konsep Siswa Kelas X Pada Materi Minyak Bumi. Hydrogen: Jurnal Kependidikan Kimia, 3(2), 294-301.

Dinni, H. N. (2018). HOTS (High Order Thinking Skills) dan kaitannya dengan kemampuan literasi matematika. PRISMA, Prosiding Seminar Nasional Matematika, 1, 170-176.

Mustofa, Z., Susilo, H., \& Al Muhdhar, M. H. I. (2016). Penerapan model pembelajaran problem based learning melalui pendekatan kontekstual berbasis lesson study untuk meningkatkan kemampuan memecahkan masalah dan hasil belajar kognitif siswa SMA. Jurnal Pendidikan: Teori, Penelitian, Dan Pengembangan, 1(5), 885-889.

Rusman. (2011). Model-model pembelajaran: Mengembangkan profesionalisme guru. Rajawali Pers/PT Raja Grafindo Persada.

Sani, R. A. (2014). Pembelajaran saintifik untuk implementasi kurikulum 2013. Bumi Aksara.

Sari, S., \& Nurohmah, S. (2016). MODEL CONTEXT BASED LEARNING (CBL) UNTUK MENGEMBANGKAN KETERAMPILAN BERPIKIR KRITIS SISWA PADA PRAKTIKUM PEMBUATAN SABUN. JTK (Jurnal Tadris Kimiya), 1(2), 64-69.

Setiawan, I., \& Nyoman, G. A. (2008). Penerapan pengajaran kontekstual berbasis masalah untuk meningkatkan hasil belajar biologi siswa kelas x2 sma laboratorium singaraja. Jurnal Penelitian Dan Pengembangan Pendidikan, 2(1), 42-59. 